\title{
Microplastic Contamination in Human Stools, Foods, and Drinking Water Associated with Indonesian Coastal Population
}

\author{
Arif Luqman ${ }^{1, * \mathbb{D}}$, Husna Nugrahapraja ${ }^{2, * \mathbb{C}}$, Ruri Agung Wahyuono ${ }^{3, *}$, Izzatul Islami ${ }^{1}$, Muhammad \\ Husain Haekal ${ }^{3}$, , Yasri Fardiansyah ${ }^{4}$, Balqis Qonita Putri ${ }^{5}$, Fahmi Ikhlasul Amalludin ${ }^{5}$, Elsalisa Ainur Rofiqa ${ }^{5}$, \\ Friedrich Götz ${ }^{6}$ and Anjar Tri Wibowo ${ }^{5, *(1)}$
}

check for updates

Citation: Luqman, A.; Nugrahapraja, H.; Wahyuono, R.A.; Islami, I.; Haekal, M.H.; Fardiansyah, Y.; Putri, B.Q.; Amalludin, F.I.; Rofiqa, E.A.; Götz, F.; et al. Microplastic Contamination in Human Stools, Foods, and Drinking Water Associated with Indonesian Coastal Population. Environments 2021, 8, 138. https: / /doi.org/10.3390/ environments 8120138

Academic Editor:

Ioannis K. Kalavrouziotis

Received: 15 November 2021 Accepted: 13 December 2021 Published: 16 December 2021

Publisher's Note: MDPI stays neutral with regard to jurisdictional claims in published maps and institutional affiliations.

Copyright: (c) 2021 by the authors. Licensee MDPI, Basel, Switzerland. This article is an open access article distributed under the terms and conditions of the Creative Commons Attribution (CC BY) license (https:// creativecommons.org/licenses/by/ $4.0 /)$.
1 Biology Department, Institut Teknologi Sepuluh Nopember, Surabaya 60111, Indonesia; izzatulislami.18013@mhs.its.ac.id

2 Biology Department, Institut Teknologi Bandung, Bandung 40132, Indonesia

3 Physics Engineering Department, Institut Teknologi Sepuluh Nopember, Surabaya 60111, Indonesia; mhaekal96@gmail.com

4 Environmental Engineering Department, Institut Teknologi Sepuluh Nopember, Surabaya 60111, Indonesia; fardiansyahyasri@gmail.com

5 Department of Biology, Faculty of Science and Technology, Airlangga University, Surabaya 60115, Indonesia; balqis.qonita.putri-2018@fst.unair.ac.id (B.Q.P.); fahmi.ikhlasul.amalludin-2018@fst.unair.ac.id (F.I.A.); elsalisa.ainur.rofiqa-2018@fst.unair.ac.id (E.A.R.)

6 Microbial Genetics Department, Eberhard Karls University of Tuebingen, 72076 Tuebingen, Germany; Friedrich.goetz@uni-tuebingen.de

* Correspondence: arif.luqman@its.ac.id (A.L.); nugrahapraja@sith.itb.ac.id (H.N.); r_agung_w@ep.its.ac.id (R.A.W.); anjar.tri@fst.unair.ac.id (A.T.W.)

Abstract: Approximately 381 million tons of plastic are produced globally every year, and the majority of it ends up as pollutants. In the environment, plastic waste is fragmented into microplastic particles less than $5 \mathrm{~mm}$ in size; owing to their small size, durability, and abundance, they can easily be dispersed, incorporated into the food chains, and enter the human body. The extent of microplastic exposure in the human body has become a major concern in many countries, including in Indonesia, the second largest plastic waste contributor in the world. Here, we report the detection of microplastics in human stools collected from a fisherman community in the coastal area of Surabaya, Indonesia. Microplastics were found in more than $50 \%$ of samples analyzed with a concentration ranging from 3.33 to $13.99 \mu \mathrm{g}$ of microplastic per gram of feces $(\mu \mathrm{g} / \mathrm{g})$. HDPE was observed as the most prevalent type of microplastic, with an average concentration of $9.195 \mu \mathrm{g} / \mathrm{g}$ in positive samples. Different types of microplastics were also detected in seafood, staple foods, drinking water, table salts, and toothpaste, which were regularly used and consumed by the study participants. Results from this preliminary study indicate widespread contamination of microplastic in the human body and in consumables associated with the coastal populations of Indonesia.

Keywords: microplastic; human stool; microplastic contamination; human exposure; waste management

\section{Introduction}

Indonesia is the second largest plastic polluting country worldwide; with nearly 17,508 islands and 54,716 km coastline, plastic pollution has become a source of major environmental problems for Indonesian marine and coastal ecosystems [1]. Nearly 1.29 million tons of plastics are entering the Indonesian ocean annually [2], high population density in coastal regions and inadequate waste management might contribute to this high pollution rate [3]. In nature, plastic waste is degraded and fragmented into smaller micro- and nanoparticles with sizes less than $5 \mathrm{~mm}$ [4]. Owing to their small size, micro-plastic can be easily dispersed and become waterborne [5-8], soil-borne [9,10], airborne pollutants [11]. From the domestic and industrial environment microplastic could enter the aquatic and terrestrial ecosystem through incomplete removal in wastewater treat-ment plants and 
its accumulation in sewage sludge $[8,12]$. Due to their abundance, dura-bility, and size, microplastic can be ingested and incorporated into the tissue and organs of various aquatic and terrestrial organisms [13]. Currently, it is established that microplastic has already entered marine food chains ]; it can be found in the gastrointestinal tracts of various marine organisms, including in fishes, bivalves, and crustaceans that are frequently consumed by humans [14-19].

Nearly 74,000 to 121,000 microplastic particles are entering the human body every year through ingestion and inhalation [20]. Exposure to microplastic might have longterm effects on human health; several works have reported potential adverse effects on the immune, nervous, and reproductive systems [21-24]. Several publications have reported microplastic contamination in various human foods and drinking water [25-27]. However, evidence for microplastic exposure in the human body remains very limited. Early evidence for human exposure came from microplastic detection in stool samples which represent contamination in the gastrointestinal tract [28-31]. It is also found in co-lectomy samples [32], saliva, the surface of skins, and head hair [33]. Recently, microplastics were also detected in human placenta [34,35] and lung tissue [36], providing evidence for microplastic penetration and incorporation in the human tissue.

The extent of microplastic exposure in the human body has become a major concern for many countries, including in Indonesia. Microplastic has been abundantly detected in Indonesian seafood [18,37,38], river fish [1,15], and salts [39] intended for human consumption. Nevertheless, reports about contamination in the human body and measurement in human specimens is still limited. Moreover, these reports are often not accompanied with data explaining the possible source of contamination (microplastic contamination rate in daily consumables, drinking water, and air associated with the study participants). In this preliminary study, we reported evidence for microplastic contamination in the human stool collected from Indonesians living in the coastal area and in the seafood, staple foods, salts, drinking water, and toothpaste that are frequently used and consumed by the study participants.

\section{Materials and Methods}

\subsection{Study Participants and Stool Sample Collection}

The stool samples were collected from 11 healthy participants (9 male and 2 female) coming from a fisherman community living in the coastal region of Kenjeran, Surabaya, Indonesia. The participants were selected on the basis of the following criteria: good general health, 20-50 years old, and did not consume any antibiotics 2 months before sample collection. The details of participants' diet and general health conditions were also recorded 7 days prior to sample collection. To ensure that no contamination of microplastics occurred during the stool sample collection, we provided the participants with a glass container with a lid and spoon made of steel. We also used glass and steel utensils during sample preparation and microplastic analysis.

\subsection{Collection of Drinking Water, Seafood, Staple Foods, Table Salts, and Toothpaste Samples}

The recorded dietary data from the participants were used as information to collect drinking water, seafood, staple foods, table salts, and toothpaste commonly used and consumed by the study participants. Drinking water was collected from 2 different brands of bottled water and 3 different drinking water refilling stations that were regularly used by the participants. Meanwhile, seafood, staple foods, table salts, and toothpaste were collected from the local markets where the participants typically acquired these products. Three replicates were collected and measured for each item. Detailed information about the analyzed consumables is provided in Supplementary Table S3.

\subsection{Sample Preparation}

Microplastics were extracted from stool, foods, salts, and toothpaste according to the previous publication [40], with some modification. Briefly, the collected stool samples and 
other samples were incubated at $70{ }^{\circ} \mathrm{C}$ for at least 1 week until the weight of the samples was constant. The dried stool samples ( $1 \mathrm{~g}$ for each sample) were mixed with $50 \mathrm{~mL}$ of Fenton solution and incubated at room temperature for $5 \mathrm{~h}$. The mixture was then subjected to filtration using cellulose nitrate-cellulose acetate filter (CN-CA filter). The filters were then digested using $65 \% \mathrm{HNO}_{3}$ at $50{ }^{\circ} \mathrm{C}$ for $30 \mathrm{~min}$ followed by incubation at $70{ }^{\circ} \mathrm{C}$ for $10 \mathrm{~min}$. The solution obtained following digestion was then diluted with distilled water at 1:2 ratio, and microplastic content in the samples was measured using Raman spectroscopy. For the collected drinking water, samples were directly subjected to Raman spectroscopy measurement without any preparation.

\subsection{Microplastic Analysis}

Microplastic identification and quantification from the digested samples were performed using Raman spectroscopy (off-resonance) with excitation wavelength of $785 \mathrm{~nm}$. StellarNet Raman HR-TEC-785 was used with a diode laser $785 \mathrm{~nm}(100 \mathrm{~mW})$ as an optical excitation. For the reference spectrum, several concentrations of microplastics were prepared by dispersing different types of microplastics, such as polyethylene terephthalate (PET), polystyrene (PS), polypropylene (PP), linear low-density polyethylene (LLDPE), high-density polyethylene (HDPE), and low-density polyethylene (LDPE) in $0.1 \mathrm{M}$ of HNO3. The spectrum profiles produced by each type of microplastic type were then used as calibration curves to quantify the microplastic content in the samples.

To identify the microplastic content in the samples, the Raman spectrums within the range of $500-2750 \mathrm{~cm}^{-1}$ were used as spectrum with the spectral identifier of each reference polymer. The Raman spectrums obtained from the samples were then fitted to the reference spectrum and calculated using the particle swarm optimization algorithm [41,42], with the following assumption:

$$
I(\omega)=\sum_{i=1}^{n} \alpha_{i} I_{i}(\omega)
$$

where $I(\omega)$ indicates the Raman spectrum of the sample, $I_{i}(\omega)$ indicates the Raman spectrum of the microplastic reference, $\alpha$ indicates the fraction of the microplastic mass, and I indicates the microplastic type index, e.g., PET, PS, PP, LLDPE, LDPE, or HDPE.

The values of $\alpha$ were then used to determine the intensity contribution of the Raman spectral identifier from each type of identified microplastic in the samples, and the intensity contribution values were used to quantify the microplastic content in the samples using the calibration curve.

To investigate the possible origin of the microplastic contamination in stool samples, we performed correlation analyses between the seafood and plastic-packaged food consumption frequency and total microplastic content in the stool samples was analyzed using Pearson's correlation with significance defined as $p<0.05$.

\subsection{Ethical Statement}

The collection of human stool samples was approved by the Health Research Ethic Committee of Universitas Surabaya (No. 005-OL/KE/III/2021). Stool samples were obtained from 11 adult participants from the highland population of Kenjeran, Surabaya, Indonesia. All samples were anonymized and obtained with written consent from the participants.

\section{Results}

\subsection{Detection of Microplastic in Human Stools}

Human stool samples were collected from 11 participants (9 males and 2 females) who came from a fisherman community living in the coastal region of Surabaya, Indonesia (Supplementary Table S1). Microplastics were detected in six participants with a total concentration ranging from 3.33 to $13.99 \mu \mathrm{g} / \mathrm{g}$ (microgram of microplastic per gram of feces). Six types of microplastics were detected across all samples, including HDPE, LDPE, LLDPE, PP, PS, and PET. Interestingly, each positive sample contained different types and compositions of microplastic, suggesting that the participant might be exposed to 
microplastic through different means. The most prevalent microplastic was HDPE, which was found in four samples with an average concentration of $9.195 \mu \mathrm{g} / \mathrm{g}$, followed by PS, which was found in two samples with an average concentration of $9.885 \mu \mathrm{g} / \mathrm{g}$. The other types of microplastic, LDPE, LLDPE, PP, and PET, were only present in one sample with average concentrations of 3.48, 7.00, 3.13, and $2.44 \mu \mathrm{g} / \mathrm{g}$, respectively (Figure 1 and Supplementary Table S2). Our results show that more than $50 \%$ of study participants had microplastic contamination in their digestive tract with HDPE detected as the most common and abundant microplastic.

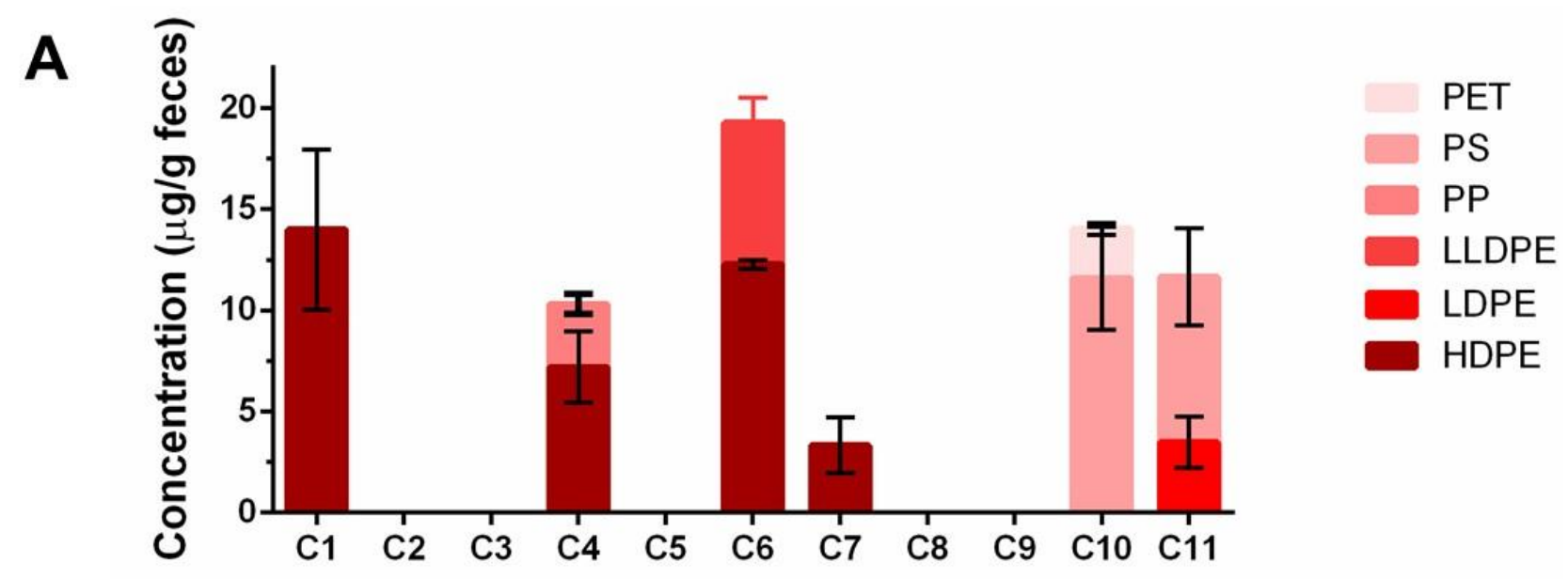

Participants

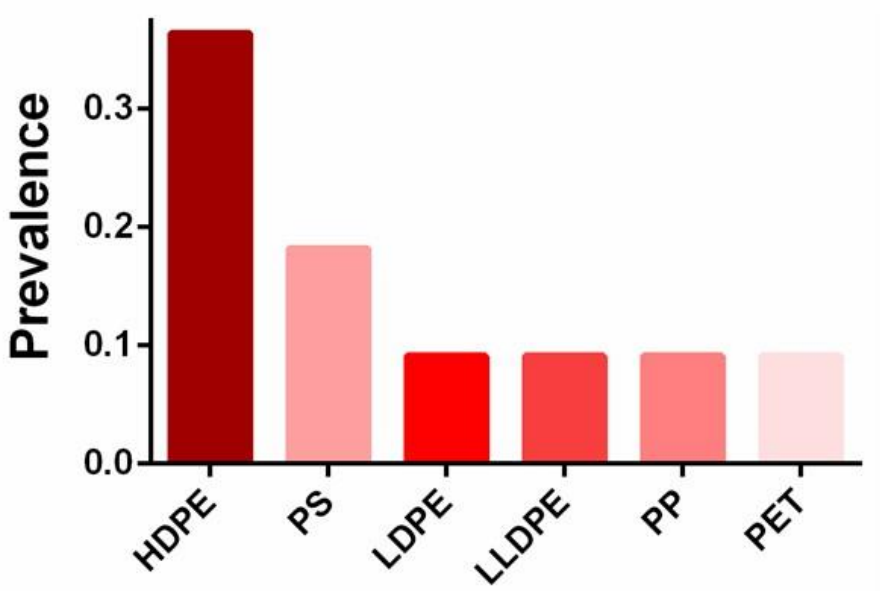

Figure 1. Concentration and prevalence of microplastics in stool samples collected from coastal populations of Kenjeran, Surabaya, Indonesia. (A) Various types of microplastics were detected in 6 out of 11 stool samples; (B) prevalence of different microplastic types in the studied population.

\subsection{Microplastic Contamination in Drinking Water}

Previous work has reported microplastic contamination in the Surabaya water supply system [43]. However, tap water in Indonesia is non-potable, and Surabaya inhabitants commonly acquire their drinking water from bottled water gallons or water refilling stations. In this study, we collected drinking water samples from two of the most popular bottled water gallon brands and three water refilling stations that were frequently used by the participants. PET was observed in one of the bottled water brands with an average concentration of $7.585 \mu \mathrm{g} / \mathrm{g}$ (microgram of microplastic per gram of water), while high concentrations of LDPE $(30.21 \mu \mathrm{g} / \mathrm{g})$ were detected from one of the water refilling stations (Table 1). These results indicate that drinking water could be a source of microplastic contamination in the studied population. However, it might not be the only source of con- 
tamination given that we could only detect PET and LDPE in the sampled water. The high abundance of HDPE found in the stool samples might originate from other consumables.

Table 1. Microplastic content in drinking water.

\begin{tabular}{ccc}
\hline Samples & Type of Microplastic & Content $(\mu \mathbf{g} / \mathbf{g})$ \\
\hline Drinking water in gallon brand 1 & PET & $9.18 \pm 1.30$ \\
Drinking water in gallon brand 2 & nd & nd \\
Drinking water in gallon from refilling station 1 & nd & nd \\
Drinking water in gallon from refilling station 2 & nd & nd \\
Drinking water in gallon from refilling station 3 & LDPE & $30.21 \pm 4.26$ \\
\hline
\end{tabular}

nd: not detected.

\subsection{Widespread Microplastic Contamination in Seafood, Staple Foods, and Hygiene Products}

Apart from drinking water, we also measured microplastic concentration in various seafood, river fish, staple foods, and table salts that were frequently consumed by the study participants (Table 2). Microplastic in the form of PP was detected in salted marine fish, while LDPE was found in marine catfish, each with concentrations of 11.61 and $5.15 \mu \mathrm{g} / \mathrm{g}$, respectively. High concentrations of PP were also found in rice $(15.36 \mu \mathrm{g} / \mathrm{g})$ and tempeh $(4.07 \mu \mathrm{g} / \mathrm{g})$, two popular staple foods in Indonesia. Rice is the main carbohydrate source for Indonesians, while tempeh (fermented soybean cake) is a staple source of proteins. To further investigate the extent of microplastic contamination in human consumables, we also measured microplastic in different brands of table salts and toothpaste regularly used by participants. All analyzed salt and toothpaste samples were found to be contaminated with microplastic, with high concentrations of PP $(8.69 \mu \mathrm{g} / \mathrm{g})$ and LLDPE $(26.27 \mu \mathrm{g} / \mathrm{g})$ found in table salts, whereas the toothpaste contained high amounts of PP $(23.47 \mu \mathrm{g} / \mathrm{g})$ and HDPE $(14.79 \mu \mathrm{g} / \mathrm{g})($ Table 3). In general, we observed widespread microplastic contamination in various consumables associated with the coastal fisherman population of Surabaya, Indonesia. Despite the relatively low number of samples we collected, we were able to detect microplastic in several seafoods, staple foods, salts, and toothpaste samples, indicating that microplastic is prevalent in human consumables.

Table 2. Microplastic content in seafood and staple foods.

\begin{tabular}{ccc}
\hline Samples & Type of Microplastic & Content $(\mu \mathrm{g} / \mathbf{g})$ \\
\hline Salted fish 1 & PP & $11.61 \pm 4.68$ \\
Salted fish 2 & nd & nd \\
Seawater catfish 1 & LDPE & $5.15 \pm 2.48$ \\
Seawater catfish 2 & nd & nd \\
Seawater catfish 3 & nd & nd \\
Mussel & nd & nd \\
Shrimp & nd & nd \\
Freshwater catfish & nd & nd \\
Tofu Brand 1 & nd & nd \\
Tofu Brand 2 & nd & nd \\
Tempeh Brand 1 & PP & $4.07 \pm 1.35$ \\
Tempeh Brand 2 & nd & nd \\
Rice Brand 1 & PP & $15.36 \pm 4.79$ \\
Rice Brand 2 & nd & nd \\
\hline
\end{tabular}


Table 3. Microplastic content in table salt and toothpaste.

\begin{tabular}{ccc}
\hline Samples & Type of Microplastic & Content $(\boldsymbol{\mu g} / \mathbf{g})$ \\
\hline & Table salt & \\
\hline Brand 1 & PP & $8.69 \pm 1.26$ \\
Brand 2 & LLDPE & $26.27 \pm 3$ \\
\hline & Toothpaste & \\
\hline Brand 1 & PP & $23.47 \pm 5.77$ \\
Brand 2 & HDPE & $14.79 \pm 5.37$ \\
\hline
\end{tabular}

\section{Discussion}

Owing to the high accumulation of plastic waste in the coastal areas and their dietary habits, coastal inhabitants, especially the fisherman community, are prone to be exposed to microplastic contamination. A long-term microplastic contamination can cause adverse effects on health [21-24]. However, the extent of microplastic contamination in the Indonesian coastal population has never been investigated before. Here, we found that more than $50 \%$ of the study participants (6 out of 11 ) have microplastic contamination in their stools. This number is lower than the previous report for microplastic contamination in the colectomy specimen collected from residents of Northeastern Peninsular Malaysia where microplastic is detected in all 11 specimens they collected [32]. A difference also exists regarding microplastic composition found in the samples, previous works reported $\mathrm{PP}$ as the most prevalent type of microplastic in human stools $[28,29,31]$ and colectomy samples [32]. However, the current study detects HDPE as the most common contaminant. Differences in microplastic prevalence and composition likely originate from variation in dietary habits, life styles, and environmental quality between the studied population, since exposure in the human body is largely dependent on microplastic intake from consumed foods and the inhaled air. To investigate possible connections between microplastic in stools with dietary habits we performed correlation analysis between microplastic occurrence in stool with frequency of consuming seafood and foods wrapped in plastic, but we did not find a statistically significant correlation between them. Note that a limited number of samples are analyzed either in this preliminary study or in previous studies, therefore, the result might not represent the overall prevalence, composition, and correlation in the general population. Follow-up studies with a higher number of sam-ples are required to establish statistically sound correlation between microplastic con-tamination in the human body and dietary habits.

Microplastic could enter the human body through food and water. To evaluate the extent of microplastic contamination in daily consumables, we also measured micro-plastic concentrations in drinking water, seafood, and staple foods that are regularly con-sumed by the participants. We found widespread microplastic contamination in various products, and it is alarmingly high in several brands of drinking water, seafood, and rice. Different types of microplastic were found in the analyzed consumables, with PP observed as the most common contaminant. The abundance of microplastic in various products might explain the diversity of microplastic composition found in the stool samples, given that participants consumed various products in differing frequencies. For example, sea-food consumption frequency among participants varies from 0 to 10 times a week with the average seafood consumption of 4.18 times in a week (Supplementary Table S1). The study participants also consume different combinations of drinking water, seafood, and staple foods packaged in plastic (Supplementary Table S1).

Apart from food and water, microplastic was also previously reported in salts [44] and toothpaste [45]. To further explore the potential source of microplastic contamination in the studied population, we also analyzed the presence of microplastic in table salts and toothpaste frequently used by the participants. All samples were contaminated with mi-croplastic, with high concentrations of PE $(26.27 \mu \mathrm{g} / \mathrm{g})$ found in one brand of table salt and HDPE $(23.47 \mu \mathrm{g} / \mathrm{g})$ in one brand of toothpaste. Considering that HDPE is the most 
com-mon type of microplastic detected in the stool samples, ingestion through toothpaste might be an important source of HDPE contamination. Apart from toothpaste, HDPE contamination might also come from plastic packaging and products. HDPE is widely used in the production of food packaging and various household items [46], previous work reported that HDPE could leach out from plastic products due to the withering pro-cess by high temperature and UV exposure [47]. The food and water by itself might not contain HDPE (as found in this study), but HDPE might leach out from the container, plastic packaging, and cooking utensils during storage and food processing. HDPE is considered to be relatively safe for humans, it is reported to have no toxic effect on the human mammary cell line [48]. Nevertheless, other work reported that HDPE exhibits es-trogenic activities that are harmful for the human reproductive system [49].

Overall, our preliminary study provides evidence for microplastic exposure in the coastal Indonesian population and high prevalence of microplastic in various human consumables. This finding is alarming because long-term microplastic contamination can cause toxicity, metabolic disturbance, and adverse health effects. Further studies with larger samples are required to estimate the rate and extent of microplastic contamination in the Indonesian population and to formulate effective mitigation strategies.

\section{Conclusions}

In this study, we were able to detect microplastics in human stools and daily consumables collected from a fishermen community in the coastal area of Indonesia. More than half of the participants (6 out of 11) have microplastic contamination in their gastrointestinal tract with HDPE detected as the most prevalent contaminant. Microplastic was also detected in daily consumables commonly used by the participants, with PP observed as the most common and abundant contaminant in foods, while LDPE was observed as the most abundant contaminant in drinking water. High concentrations of HDPE were found in toothpaste; since this type of microplastic was abundant in stool samples, intake of HDPE from toothpaste might be an important but underestimated source of microplastic contamination. Taken together, we have provided evidence for the widespread contamination of microplastic in the Indonesian coastal population, both in the human body and in various daily consumables. Results from these preliminary studies can be used as a basis for follow-up work with larger and more diverse participants to find correlations between microplastic exposure and dietary habits, calculating microplastic intake rate per capita, and to fully elucidate the extent of microplastic contamination in the Indonesian population.

Supplementary Materials: The following are available online at https:/ /www.mdpi.com/article/10 .3390 /environments8120138/s1, Table S1: Microplastic concentration found in participants' stool samples, Table S2: Summary of data collected from interview with participants and the total of microplastics found in each stool sample, Table S3: Detailed informations about the analyzed consumables.

Author Contributions: Conceptualization, A.T.W., A.L., H.N.; methodology, A.T.W., A.L.; formal analysis, A.T.W., A.L., R.A.W.; investigation, I.I., M.H.H., Y.F., B.Q.P., F.I.A., E.A.R.; resources, A.T.W., A.L., R.A.W., F.G.; data curation, A.T.W., H.N., A.L., R.A.W.; writing-original draft preparation, A.T.W., A.L.; supervision, A.T.W., H.N., A.L.; project administration, A.T.W., H.N., A.L.; funding acquisition, A.T.W., H.N., A.L. All authors have read and agreed to the published version of the manuscript.

Funding: This research was funded by the PPKI program from the Indonesian World Class University Research Scheme (1325/PKS/ITS/2021; 177/UN3.15/PT/2021; 542/IT1.B07.1/TA.00/2021).

Institutional Review Board Statement: The collection of human stool samples was approved by the Health Research Ethic Committee of Universitas Surabaya (No. 005-OL/KE/III/2021). Stool samples were obtained from 11 adult participants from the highland population of Pacet, Mojokerto, Indonesia. All samples were anonymized and obtained with written consent from the participants.

Informed Consent Statement: Informed consent was obtained from all subjects involved in the study. Written informed consent has been obtained from the patient(s) to publish this paper. 
Acknowledgments: We acknowledge a collaborative PPKI program from the Indonesian World Class University Research Scheme.

Conflicts of Interest: The authors declare no conflict of interest. The funders had no role in the design of the study; in the collection, analyses, or interpretation of data; in the writing of the manuscript, or in the decision to publish the results.

\section{References}

1. Vriend, P.; Hidayat, H.; van Leeuwen, J.; Cordova, M.R.; Purba, N.P.; Löhr, A.J.; Faizal, I.; Ningsih, N.S.; Agustina, K.; Husrin, S.; et al. Plastic Pollution Research in Indonesia: State of Science and Future Research Directions to Reduce Impacts. Front. Environ. Sci. 2021, 9, 692907. [CrossRef]

2. Jambeck, J.R.; Geyer, R.; Wilcox, C.; Siegler, T.R.; Perryman, M.; Andrady, A.; Narayan, R.; Law, K.L. Plastic waste inputs from land into the ocean. Science 2015, 347, 768-771. [CrossRef]

3. Lestari, P.; Trihadiningrum, Y. The impact of improper solid waste management to plastic pollution in Indonesian coast and marine environment. Mar. Pollut. Bull. 2019, 149, 110505. [CrossRef]

4. Hartmann, N.B.; Hüffer, T.; Thompson, R.C.; Hassellöv, M.; Verschoor, A.; Daugaard, A.E.; Rist, S.; Karlsson, T.; Brennholt, N.; Cole, M.; et al. Are We Speaking the Same Language? Recommendations for a Definition and Categorization Framework for Plastic Debris. Environ. Sci. Technol. 2019, 53, 1039-1047. [CrossRef] [PubMed]

5. Luo, W.; Su, L.; Craig, N.J.; Du, F.; Wu, C.; Shi, H. Comparison of microplastic pollution in different water bodies from urban creeks to coastal waters. Environ. Pollut. 2019, 246, 174-182. [CrossRef] [PubMed]

6. Sharma, S.; Sharma, V.; Chatterjee, S. Microplastics in the Mediterranean Sea: Sources, Pollution Intensity, Sea Health, and Regulatory Policies. Front. Mar. Sci. 2021, 8, 634934. [CrossRef]

7. Marrone, A.; La Russa, M.F.; Randazzo, L.; La Russa, D.; Cellini, E.; Pellegrino, D. Microplastics in the Center of Mediterranean: Comparison of the Two Calabrian Coasts and Distribution from Coastal Areas to the Open Sea. Int. J. Environ. Res. Public Health 2021, 18, 10712. [CrossRef]

8. Karapanagioti, H.K.; Kalavrouziotis, I.K. Microplastics in Water and Wastewater; IWA Publishing: London, UK, 2019; ISBN 9781789060027.

9. Tudor, V.C.; Mocuta, D.N.; Teodorescu, R.F.; Smedescu, D.I. The Issue of Plastic and Microplastic Pollution in Soil. Mater. Plast. 2019, 56, 484-487. [CrossRef]

10. Xu, C.; Zhang, B.; Gu, C.; Shen, C.; Yin, S.; Aamir, M.; Li, F. Are we underestimating the sources of microplastic pollution in terrestrial environment? J. Hazard. Mater. 2020, 400, 123228. [CrossRef]

11. Prata, J.C. Airborne Microplastics: Consequences to Human Health? Environ. Pollut. 2018, 234, 115-126. [CrossRef]

12. Collivignarelli, M.C.; Miino, M.C.; Caccamo, F.M.; Milanese, C. Microplastics in Sewage Sludge: A Known but Underrated Pathway in Wastewater Treatment Plants. Sustainability 2021, 13, 12591. [CrossRef]

13. Wong, J.K.H.; Lee, K.K.; Tang, K.H.D.; Yap, P.-S. Microplastics in the freshwater and terrestrial environments: Prevalence, fates, impacts and sustainable solutions. Sci. Total Environ. 2020, 719, 137512. [CrossRef] [PubMed]

14. Baalkhuyur, F.M.; Bin Dohaish, E.J.; Elhalwagy, M.E.; Alikunhi, N.M.; AlSuwailem, A.M.; Røstad, A.; Coker, D.J.; Berumen, M.; Duarte, C.M. Microplastic in the gastrointestinal tract of fishes along the Saudi Arabian Red Sea coast. Mar. Pollut. Bull. 2018, 131, 407-415. [CrossRef] [PubMed]

15. Cordova, M.R.; Riani, E.; Shiomoto, A. Microplastics ingestion by blue panchax fish (Aplocheilus sp.) from Ciliwung Estuary, Jakarta, Indonesia. Mar. Pollut. Bull. 2020, 161, 111763. [CrossRef]

16. Ismail, M.R.; Lewaru, M.W.; Prihadi, D.J. Microplastics Ingestion by Fish in the Pangandaran Bay, Indonesia. World News Nat. Sci. Int. Sci. J. 2019, 23, 173-181.

17. Lusher, A.; McHugh, M.; Thompson, R. Occurrence of microplastics in the gastrointestinal tract of pelagic and demersal fish from the English Channel. Mar. Pollut. Bull. 2013, 67, 94-99. [CrossRef]

18. Rochman, C.M.; Tahir, A.; Williams, S.L.; Baxa, D.V.; Lam, R.; Miller, J.T.; Teh, F.-C.; Werorilangi, S.; Teh, S.J. Anthropogenic debris in seafood: Plastic debris and fibers from textiles in fish and bivalves sold for human consumption. Sci. Rep. 2015, 5, 14340. [CrossRef] [PubMed]

19. Danopoulos, E.; Jenner, L.C.; Twiddy, M.; Rotchell, J.M. Microplastic Contamination of Seafood Intended for Human Consumption: A Systematic Review and Meta-Analysis. Environ. Health Perspect. 2020, 128, 126002. [CrossRef]

20. Cox, K.D.; Covernton, G.A.; Davies, H.L.; Dower, J.F.; Juanes, F.; Dudas, S.E. Human Consumption of Microplastics. Environ. Sci. Technol. 2019, 53, 7068-7074. [CrossRef] [PubMed]

21. Hwang, J.; Choi, D.; Han, S.; Jung, S.Y.; Choi, J.; Hong, J. Potential toxicity of polystyrene microplastic particles. Sci. Rep. 2020, 10, 7391. [CrossRef] [PubMed]

22. Prata, J.C.; da Costa, J.P.; Lopes, I.; Duarte, A.C.; Rocha-Santos, T. Environmental exposure to microplastics: An overview on possible human health effects. Sci. Total Environ. 2020, 702, 134455. [CrossRef]

23. Sharma, S.; Chatterjee, S. Microplastic pollution, a threat to marine ecosystem and human health: A short review. Environ. Sci. Pollut. Res. 2017, 24, 21530-21547. [CrossRef] [PubMed]

24. Smith, M.; Love, D.C.; Rochman, C.M.; Neff, R.A. Microplastics in Seafood and the Implications for Human Health. Curr. Environ. Health Rep. 2018, 5, 375-386. [CrossRef] [PubMed] 
25. Kedzierski, M.; Lechat, B.; Sire, O.; Le Maguer, G.; Le Tilly, V.; Bruzaud, S. Microplastic contamination of packaged meat: Occurrence and associated risks. Food Packag. Shelf Life 2020, 24, 100489. [CrossRef]

26. Pivokonsky, M.; Cermakova, L.; Novotna, K.; Peer, P.; Cajthaml, T.; Janda, V. Occurrence of microplastics in raw and treated drinking water. Sci. Total Environ. 2018, 643, 1644-1651. [CrossRef]

27. Santillo, D.; Miller, K.; Johnston, P. Microplastics as contaminants in commercially important seafood species. Integr. Environ. Assess. Manag. 2017, 13, 516-521. [CrossRef] [PubMed]

28. Schwabl, P.; Köppel, S.; Königshofer, P.; Bucsics, T.; Trauner, M.; Reiberger, T.; Liebmann, B. Detection of Various Microplastics in Human Stool: A Prospective Case Series. Ann. Intern. Med. 2019, 171, 453-457. [CrossRef]

29. Zhang, N.; Bin Li, Y.; He, H.R.; Zhang, J.F.; Ma, G.S. You are what you eat: Microplastics in the feces of young men living in Beijing. Sci. Total Environ. 2021, 767, 144345. [CrossRef] [PubMed]

30. Zhang, J.; Wang, L.; Trasande, L.; Kannan, K. Occurrence of Polyethylene Terephthalate and Polycarbonate Microplastics in Infant and Adult Feces. Environ. Sci. Technol. Lett. 2021, 8, 989-994. [CrossRef]

31. Wibowo, A.T.; Nugrahapraja, H.; Wahyuono, R.A.; Islami, I.; Haekal, M.H.; Fardiansyah, Y.; Sugiyo, P.W.W.; Putro, Y.K.; Fauzia, F.N.; Santoso, H.; et al. Microplastic Contamination in the Human Gastrointestinal Tract and Daily Consumables Associated with an Indonesian Farming Community. Sustain. Sci. Pract. Policy 2021, 13, 12840. [CrossRef]

32. Ibrahim, Y.S.; Anuar, S.T.; Azmi, A.A.; Khalik, W.M.A.W.M.; Lehata, S.; Hamzah, S.R.; Ismail, D.; Ma, Z.F.; Dzulkarnaen, A.; Zakaria, Z.; et al. Detection of microplastics in human colectomy specimens. JGH Open 2021, 5, 116-121. [CrossRef] [PubMed]

33. Abbasi, S.; Turner, A. Human exposure to microplastics: A study in Iran. J. Hazard. Mater. 2021, 403, 123799. [CrossRef] [PubMed]

34. Braun, T.; Ehrlich, L.; Henrich, W.; Koeppel, S.; Lomako, I.; Schwabl, P.; Liebmann, B. Detection of Microplastic in Human Placenta and Meconium in a Clinical Setting. Pharmaceutics 2021, 13, 921. [CrossRef] [PubMed]

35. Ragusa, A.; Svelato, A.; Santacroce, C.; Catalano, P.; Notarstefano, V.; Carnevali, O.; Papa, F.; Rongioletti, M.C.A.; Baiocco, F.; Draghi, S.; et al. Plasticenta: First evidence of microplastics in human placenta. Environ. Int. 2021, 146, 106274. [CrossRef]

36. Amato-Lourenço, L.F.; Carvalho-Oliveira, R.; Júnior, G.R.; Galvão, L.D.S.; Ando, R.A.; Mauad, T. Presence of airborne microplastics in human lung tissue. J. Hazard. Mater. 2021, 416, 126124. [CrossRef]

37. Hastuti, A.R.; Lumbanbatu, D.T.; Wardiatno, Y. The presence of microplastics in the digestive tract of commercial fishes off Pantai Indah Kapuk coast, Jakarta, Indonesia. Biodiversitas J. Biol. Divers. 2019, 20, 1233-1242. [CrossRef]

38. Khoironi, A.; Anggoro, S. The Existence of Microplastic in Asian Green Mussels. IOP Conf. Ser. Earth Environ. Sci. 2018, 131, 012050. [CrossRef]

39. Dwiyitno, D.; Sturm, M.T.; Januar, H.I.; Schuhen, K. Influence of various production methods on the microplastic contamination of sea salt produced in Java, Indonesia. Environ. Sci. Pollut. Res. 2021, 28, 30409-30413. [CrossRef]

40. Yan, Z.; Zhao, H.; Zhao, Y.; Zhu, Q.; Qiao, R.; Ren, H.; Zhang, Y. An efficient method for extracting microplastics from feces of different species. J. Hazard. Mater. 2020, 384, 121489. [CrossRef] [PubMed]

41. Wahyuono, R.A.; Hesse, J.; Hipler, U.-C.; Elsner, P.; Böhm, V. Carotenoids of Indigenous Citrus Species from Aceh and Its in Vitro Antioxidant, Antidiabetic and Antibacterial Activities. Eur. Food Res. Technol. 2016, 242, 1869-1881.

42. Wahyuono, R.A.; Hesse, J.; Hipler, U.-C.; Elsner, P.; Böhm, V. In Vitro Lipophilic Antioxidant Capacity, Antidiabetic and Antibacterial Activity of Citrus Fruits Extracts from Aceh, Indonesia. Antioxid. Redox Signal 2017, 6, 11.

43. Radityaningrum, A.D.; Trihadiningrum, Y.; Soedjono, E.S.; Herumurti, W. Microplastic Contamination in Water Supply and the Removal Efficiencies of the Treatment Plants: A Case of Surabaya City, Indonesia. J. Water Process. Eng. 2021, $43,102195$. [CrossRef]

44. Kim, J.-S.; Lee, H.-J.; Kim, S.-K.; Kim, H.-J. Global Pattern of Microplastics (MPs) in Commercial Food-Grade Salts: Sea Salt as an Indicator of Seawater MP Pollution. Environ. Sci. Technol. 2018, 52, 12819-12828. [CrossRef] [PubMed]

45. Ustabaş1, G.S.; Baysal, A. Occurrence and risk assessment of microplastics from various toothpastes. Environ. Monit. Assess. 2019, 191, 438. [CrossRef] [PubMed]

46. Rodrigues, M.; Abrantes, N.; Gonçalves, F.; Nogueira, H.S.; Marques, J.; Gonçalves, A.M. Impacts of plastic products used in daily life on the environment and human health: What is known? Environ. Toxicol. Pharmacol. 2019, 72, 103239. [CrossRef] [PubMed]

47. Hsueh, H.-C.; Kim, J.H.; Orski, S.; Fairbrother, A.; Jacobs, D.; Perry, L.; Hunston, D.; White, C.; Sung, L. Micro and macroscopic mechanical behaviors of high-density polyethylene under UV irradiation and temperature. Polym. Degrad. Stab. 2020, 174, 109098. [CrossRef]

48. Zimmermann, L.; Dierkes, G.; Ternes, T.A.; Völker, C.; Wagner, M. Benchmarking the in Vitro Toxicity and Chemical Composition of Plastic Consumer Products. Environ. Sci. Technol. 2019, 53, 11467-11477. [CrossRef] [PubMed]

49. Real, M.; Molina-Molina, J.-M.; Jiménez-Díaz, I.; Arrebola, J.P.; Sáenz, J.-M.; Fernández, M.F.; Olea, N. Screening of hormonelike activities in bottled waters available in Southern Spain using receptor-specific bioassays. Environ. Int. 2015, 74, 125-135. [CrossRef] 